\title{
HIGH COORDINATION AND EQUITABLE PARENTAL EFFORT IN THE RUFOUS HORNERO
}

\author{
Viviana Massoni ${ }^{1,3}$, Juan C. Reboreda ${ }^{1}$, Gabriela C. López ${ }^{2}$, And M. Florencia Aldatz ${ }^{1}$ \\ ${ }^{1}$ Departamento de Ecología, Genética y Evolución, Facultad de Ciencias Exactas y Naturales, \\ Universidad de Buenos Aires, Intendente Güiraldes 2160, C1428EGA, \\ Capital Federal, Argentina \\ ${ }^{2}$ Instituto de Investigaciones Biotecnológicas (IIB-INTECH), Chascomús, Buenos Aires, Argentina
}

\begin{abstract}
In temperate regions of the Southern Hemisphere, avian parental care is understudied, in particular for the neotropical family Furnariidae. We measured rates of nest building, mud carrying, incubation, brooding, feeding, and nest-sanitation behaviors of molecularly sexed Rufous Horneros (Furnarius rufus) nesting in the humid pampas of Argentina. We also evaluated the coordination of all these behaviors between the partners, and compared the frequency of uncoordinated behaviors of each sex. Males and females worked equitably throughout the nesting cycle with few exceptions: (1) both sexes built the nest, but males supplied somewhat less mud at the beginning of nest construction, (2) though highly involved in incubating the eggs males did so slightly less often than females during early incubation, (3) even if males also brooded the nestlings, they brooded less often and for slightly briefer periods than did females, and (4) young nestlings were fed less often by males than by females. We found no differences in nest-sanitation rates. The proportion of behaviors coordinated between partners performing different parental tasks was very high through the entire nesting cycle. Analysis of the frequency of uncoordinated behaviors revealed females were more prone than males to skip turns only at the onset of nest building and the beginning of the nestling period. The sexes' similar and coordinated effort is probably essential for the building of the Rufous Hornero's remarkable nest and reaching the high rate of nest success that characterizes the species.
\end{abstract}

Key words: biparental effort, coordinated behavior, Furnarius rufus, nesting success, Rufous Hornero.

\section{Alta Coordinación y Esfuerzo Parental Equitativo en Furnarius rufus}

Resumen. El cuidado parental ha sido poco estudiado en aves del Hemisferio Sur templado, en particular dentro de la familia neotropical Furnariidae. Medimos las tasas de construcción del nido, acarreo de barro, incubación, empolle, alimentación y limpieza que realizaron machos y hembras (sexo determinado molecularmente) de Furnarius rufus que nidifican en la pampa húmeda de Argentina. Además, evaluamos la coordinación de todos estos comportamientos entre los miembros de la pareja y comparamos la proporción de comportamientos no coordinados de cada sexo. Machos y hembras trabajaron con alta equitatividad a lo largo de todo el ciclo de nidificación, con escasas excepciones: (a) machos y hembras construyeron el nido a la par, pero los machos acarrearon ligeramente menos barro al nido al inicio de la construcción, (b) si bien ambos sexos participaron activamente de la incubación, los machos incubaron por periodos ligeramente más cortos, (c) aunque los machos también empollaron pichones, lo hicieron con menor frecuencia y por períodos más cortos, y (d) los pichones pequeños recibieron menos visitas de alimentación de sus padres que de sus madres. No encontramos diferencias en las tasas de limpieza del nido. La proporción de comportamientos coordinados con la pareja fue muy alta durante todo el ciclo de nidificación. La alta similitud y coordinación del esfuerzo parental probablemente es esencial para construir su extraordinario nido y alcanzar el alto éxito reproductivo que caracteriza a esta especie.

\section{INTRODUCTION}

Parental care is closely related to the social mating system (Emlen and Oring 1977) and, though 90\% of avian species are socially monogamous (Lack 1968), true genetic monogamy occurs in only $14 \%$ of passerine species (Griffith et al. 2002). The resulting lack of genetic relatedness between fathers and offspring may strengthen the conflict of interests between the sexes with respect to optimal investment in parental care (Trivers 1972). Females of species with biparental care are typically involved in all or most parental duties, generally including building the nest, incubating the eggs, and rearing the offspring (Lack 1968, Clutton-Brock 1991). Males, in contrast, are commonly involved in feeding young but are less frequently involved in incubating the eggs and brooding the chicks (Silver et al. 1985, Ketterson and Nolan 1994). Thus most research on the paternal contribution in passerines with biparental care has focused on rates of provisioning chicks, even though incubation has been acknowledged as

Manuscript received 23 August 2011; accepted 16 February 2012.

[3-mail: massoni@ege.fcen.uba.ar

The Condor, Vol. 114, Number 3, pages 564-570. ISSN 0010-5422, electronic ISSN 1938-5422. C 2012 by The Cooper Ornithological Society. All rights reserved. Please direct all requests for permission to photocopy or reproduce article content through the University of California Press's Rights and Permissions website, http://www.ucpressjournals.com/ reprintInfo.asp. DOI: 10.1525/cond.2012.110135 
an energetically costly component of parental care (Williams 1996, Reid et al. 2002a), and brooding, as an extension of incubation, is costly too (Pearson 1994). The male's involvement in nest building, incubation, and brooding remains poorly understood (Whittingham and Dunn 2001, but see Reid et al. 2002a,Van Roo et al. 2003, Auer et al. 2007).

The quality of an individual as a mate may depend not only on its individual traits but also on how its traits mesh with those of its mate (Ens et al. 1993, Zeh and Zeh 2001, Dingemanse et al. 2004). Indeed, the compatibility of the members of the pair during the nestling period has been shown to affect the reproductive success of some species (Spoon et al. 2006). Behavioral complementarity and coordination may be regarded as specific cases of compatibility. Complementarity arises when mates specialize in different contributions to reproduction, while coordination comprises those cases in which mates trade off carrying out the same type of tasks (Spoon et al. 2006).

The Furnariidae are a large neotropical family of birds that includes 236 species in 56 genera (Remsen 2003). In spite of their ubiquity in South America and their relative abundance, their lack of sexual dimorphism in size and color has delayed the study of how each sex contributes to parental duties (Remsen 2003). It is generally accepted that the contribution of males is high (Remsen 2003), but the involvement of both sexes in incubation and chick feeding has been confirmed in only eight species (Fraga 1980, Nores and Nores 1994, Remsen 2003, Moreno et al. 2007) and is suspected in another five species (Remsen 2003, Hahn et al. 2004).

The Rufous Hornero (Furnarius rufus) is an ideal species with which to study the extent of parental care provided by males and females and the existence of behavioral complementarity and coordination in parental duties. It is socially monogamous (Fraga 1980) and builds a conspicuously exposed large "oven" nest consisting of mud mixed with grass or dung. The wall of the nest is between 3 and $5 \mathrm{~cm}$ thick and the nest may weigh up to $5 \mathrm{~kg}$ (Remsen 2003). Building this structure represents a large effort, as the species' body mass is only around $60 \mathrm{~g}$ (Fraga 1980, Aldatz 2006) and the weight of the nest is up to 80 times the bird's weight. Rufous Horneros build a new nest each year (Fraga 1980), and nest building typically takes $2-3$ months, although in some cases it can take only 15 days (Fraga 1980). Remsen (2003) proposed that this extraordinary nest, and its ability to mediate the effect of extreme temperatures, is responsible for the Rufous Hornero's wide geographic distribution and high nesting success $(72 \%$, Fraga 1980; 71\%, Mason 1985; 62\%, Aldatz 2006), as well as the enhanced nesting success of other species that use their nests (e.g., Saffron Finches, Sicalis flaveola, had higher nesting success when using Rufous Hornero nests than when using other cavities, Mason 1985).

The information available on the extent of parental care provided by males and females is scant. In the most detailed work on the breeding biology and behavior of the species,
Fraga (1980) reported that the male is "helped" by the female during nest construction, but he provided no information on the relative contribution of each sex to nest building. Both sexes incubate the eggs, but the length and frequency of each sex's incubation shifts is unknown. Finally, although both sexes deliver food at similar rates (Fraga 1980), quantitative data on feeding through the nestling period is lacking. Therefore, available information on parental care does not accurately represent the contribution of each sex to parental duties or the extent of coordination of those behaviors through the nesting cycle.

The aim of our study was to determine the extent of parental care male and female Rufous Horneros provided during nest building, incubation, and chick brooding and feeding. We also evaluated the equitability and coordination of the sexes' efforts through the entire nestling period in a molecularly sexed population. Given that pairs of the Rufous Hornero remain together throughout the breeding season, sometimes over multiple years, are territorial year round, and intolerant of conspecifics' intrusions (Fraga 1980), we expected both males and females to be highly and equitably committed to most or all parental chores and to find high levels of coordination between the sexes for many nesting behaviors.

\section{METHODS}

Our study took place in a flat agricultural landscape at the Instituto Tecnológico de Chascomús, Buenos Aires Province $\left(35^{\circ} 34^{\prime} \mathrm{S}, 58^{\circ} 01^{\prime} \mathrm{W}\right.$ ), during the breeding seasons (September to December) of 2002, 2003, and 2004. The site is within the "flooding pampas" (Soriano 1991). Annual rainfall is approximately $1100 \mathrm{~mm}$, and mean monthly temperatures during the breeding season vary from $12{ }^{\circ} \mathrm{C}$ (September) to $20^{\circ} \mathrm{C}$ (December). Our study site is used mainly for raising cattle. The area is divided in paddocks whose borders are vegetated with Celtis tala and Acacia bonariensis, in which we found the majority of nests. We also found some nests on artificial structures such as fence poles.

\section{STUDY SPECIES}

Like most species in the Furnariidae, the Rufous Hornero does not show evident sexual dichromatism. In both males and females, the dorsal parts are rufous, the wing has a slight band, and the underparts are brownish grey or light cinnamon (Narosky and Yzurieta 1987). Because of their similarity in size as well as morphology (Fraga 1980) the sexes are not distinguishable in the field, though they may be identified at a distance by vocal differences while they duet (Roper 2005). The species' distribution extends from northeastern Brazil south to Neuquén and Río Negro provinces in Argentina. The Rufous Hornero is commonly associated with humans, who provide additional substrates for nests and the water needed to build them. 


\section{DATA COLLECTION}

We searched for nests systematically within our study site and followed 59 attempted nests (20, 16, and 23 in 2002, 2003, and 2004, respectively). We found 41 nests while being built and 18 with eggs. The final stage of nest building is the construction of the egg chamber: from both sides of the entrance a curved wall of mud enters the nest, reducing the opening and forming a rounded chamber. Females may start to lay before the chamber is finished (Fraga 1980), so we started checking the nests' contents as soon as construction of the chamber began. We checked nests every day during laying to track clutch completion and every other day during incubation and chick rearing to track nest fate. Because the egg chamber is closed we had to open the back of each nest by cutting a circular hole $6 \mathrm{~cm}$ in diameter in the back of the egg chamber with a circular saw. Following Fraga (1980), we carefully sealed the hole with a wooden plug and mud after each visit. We avoided opening the nests on windy or rainy days. To our knowledge, no nest was abandoned as a result of our checking it.

We captured the adults in mist nets (60-mm mesh) placed close to the nest. We broadcast recordings of calls to attract the territorial pair to the net. We banded the birds with a unique combination of three color bands and a numbered aluminum band. Because the Rufous Hornero is sexually monomorphic, we sexed the birds genetically by means of DNA isolated from blood samples according to the procedures suggested by Quintana et al. (2008). At the time of capture, using a heparinized capillary tube we collected 20 - to $40-\mu \mathrm{L}$ sample of blood from each bird via brachial venipuncture. We placed each sample on a $20-\times 10-\mathrm{mm}$ piece of commercial filter paper. Samples were air-dried and stored separately at room temperature in small sealed plastic bags until analysis. The highly conserved CHD1 gene on the sex chromosomes contains introns of different lengths in each sex. We used a forward primer (2550F) and a reverse primer (2718R) to amplify both the CHD1-W and CHD1-Z genes (Fridolfsson and Ellegren 1999), then visualized the different sized introns to determine the sex of each bird.

We recorded the male's and female's parental behavior during nest building, incubation, and feeding of nestlings by video recording activity at the nest for intervals of $2 \mathrm{hr}$ and checked the nest's contents at the end of each session of recording. We videotaped nests at random from 07:00 to 18:00 to maximize the number of nests we could record at on a given day, as a pilot study did not reveal differences in parental behavior with time of the day. Because of inclement weather and nest predation we were unable to video-record all the nests at all stages of interest. Some nests were videorecorded only once, others several times through the nesting cycle, but we video-recorded each nest only once during each period of interest. We used Sony Hi-8 CCD-TRV 138 cameras placed at least $20 \mathrm{~m}$ from the nest. We recorded $62 \mathrm{hr}$ during nest building ( $n=19$ nests), $126 \mathrm{hr}$ during incubation $(n=23$ nests), and $84 \mathrm{hr}$ during the nestling period ( $n=19$ nests), totaling $280 \mathrm{hr}$.

We divided nest building into an initial construction stage during which the birds were constructing the main structure (floor, walls, and roof) and an advanced construction stage, when birds were building the inner wall to form the nest chamber. Using video observations, we recorded for each sex separately the rate of mud carrying (number of visits $\mathrm{hr}^{-1}$ at which the individual was transporting building material) and the rate of building rate (number of visits $\mathrm{hr}^{-1}$ where birds molded nest material with their beaks) because birds could have performed one or both behaviors during a visit to the nest. We calculated the proportion of coordinated visits and the frequency of uncoordinated behaviors of each sex. We defined a visit as coordinated if the behavior during the visit was the same as that during a previous visit by the opposite sex and uncoordinated if the male or female repeated a particular behavior before its mate did. We also determined the frequency of uncoordinated, repetitive behaviors of each sex. We recorded incubation activity of each sex at three points during incubation: early incubation ( $2 \pm 1$ days since the start of incubation), middle incubation ( $9 \pm 1$ days), and late incubation (15 \pm 1 days). For each sex we analyzed the length (min:sec), and frequency $\left(\mathrm{hr}^{-1}\right)$ of incubation shifts, the proportion of coordinated incubation shifts, and the frequency of uncoordinated incubation visits made by each sex. We recorded activity during the nestling period during three stages defined by the chicks' age: early ( $5 \pm 1$ days of age with the day of hatching $=$ age 0$)$, middle $(11 \pm 1$ days of age $)$, and late $(18 \pm 1$ days of age). For each parent we calculated the rates of feeding (number of visits nestling ${ }^{-1} \mathrm{hr}^{-1}$ ) and fecal-sac removal (number of sac-removal visits nestling ${ }^{-1} \mathrm{hr}^{-1}$ ). We calculated the proportion of coordinated feeding visits for all periods and the frequency of uncoordinated feeding visits made by each sex. For the early nestling period, we calculated the brooding rate (number of visits $\mathrm{hr}^{-1}$ to brood), the length of brooding shifts (min:sec), brooding coordination, and frequency of uncoordinated brooding behavior of each sex. In the video recordings, we observed no removals of fecal sacs during the early nestling period, and no instances of brooding during the middle and late nestling period. We did not calculate the frequency of uncoordinated removals of fecal sacs because of their small number (see Results). Because we found no differences by year in any of the behaviors, we pooled all years for analysis. Numbers of nests at different stages vary because some nests were found at an advanced stage of nest construction and some nests failed during incubation or after hatching.

\section{STATISTICAL ANALYSIS}

We described the behaviors of each sex, recording the median value and lower and upper quartiles. Behavioral variables were not normally distributed and not all could be transformed to meet the assumption of normality for parametric 
tests. Because of this, we compared the effort made by males and females with Wilcoxon matched-pair tests. To evaluate the significance of results we calculated the $95 \%$ confidence interval for the median difference between males and females (Daniel 1978), as suggested by Colegrave and Ruxton (2003). The proportion of coordinated behaviors was usually high (see Results); however, to determine if one sex was more prone to assume a larger involvement in a particular task by repeating uncoordinated behaviors, we described and compared the frequency of uncoordinated behaviors of each sex by the same methods described above. For our analyses we used Statistica 7.0. (Statsoft, Inc.).

\section{RESULTS}

We tracked 59 nests during this study. Sixty-two percent $(37 / 59)$ were successful and fledged at least one young. The causes of nest failure were predation $(66 \%, n=15)$, the nest falling after extraordinarily heavy rain $(30 \%, n=7)$, and nest abandonment after the brood-parasitic Shiny Cowbird (Molothrus bonariensis) punctured an egg $(4 \%, n=1)$. Four nests were parasitized by Shiny Cowbirds, and in all cases the horneros ejected the cowbird egg.

\section{EFFORT AND COORDINATION OF THE SEXES IN PARENTAL CARE}

Both males and females participated actively and equitably in nest-building chores with some exceptions. During the initial stage of building, females carried material significantly more often to the nest than did males (Table 1). Although the proportion of coordinated visits was high ( 0.7 for visits to both build and carry mud), the frequency of uncoordinated behaviors showed females were more prone to repeat the carrying of mud before their partners did (Table 2). During the advanced stage of nest building the proportion of coordinated building behavior was high (0.8), that of mud-carrying behavior lower (0.4). Nonetheless, neither sex was more prone to behave without coordination than the other (Table 2).
Both sexes contributed similarly to incubation but differed somewhat at the onset of incubation. Early in incubation, females made more visits than did males, and those visits tended to be longer, but during the middle and later periods of incubation the number and length of visits to incubate did not differ (Table 3 ). The proportion of coordinated visits was very high $(0.8,0.8$, and 0.9 during the initial, middle, and advanced segments of incubation, respectively). The frequency of uncoordinated visits was too small to allow statistical comparison. During the initial phase of the nestling period females fed chicks more often than did males. Though males brooded often and actively, females brooded slightly more often than did males and for longer periods (Table 4). At this early age no adult was seen carrying fecal sacs away from the nest. During the middle and advanced phases of the nestling period, when nestlings were 11 and 18 days of age, respectively, males and females removed fecal sacs at the same rates (Table 4). During the early nestling period, although behaviors were coordinated in high proportion ( 0.7 and 0.6 of visits for feeding and brooding, respectively), the sexes differed: uncoordinated visits to feed and brood were made more often by females (Table 2 ). The proportion of coordinated visits to feed fell to 0.5 during the middle and late nestling periods, but the frequency of uncoordinated visits was similar in both sexes (Table 2). The frequency of the sexes' visits to remove fecal sacs during the last two stages was similar (Table 4) and too low for us to detect whether uncoordinated behaviors were made more often by one sex or the other.

\section{DISCUSSION}

Our study demonstrates that in the Rufous Hornero parental care is equally distributed and highly coordinated between the sexes. We found that females build at the same or a slightly higher rate than do males during the early stage of nest construction and their coordination of mud-carrying visits during the advanced nest-building stage is somewhat less. The task of

TABLE 1. Median, lower, and upper quartiles of rates of visits for nest building and mud carrying by males and females during the initial and advanced stage of nest building (see Methods). The effort of each sex is compared by a Wilcoxon matched-pairs test and the $95 \%$ confidence interval for the difference between the median values for males and females ( $\mathrm{M}$ diff. $\widehat{\partial}-\stackrel{0}{)}$.

\begin{tabular}{|c|c|c|c|c|c|c|c|c|c|c|c|c|}
\hline \multirow[b]{2}{*}{ Stage and variable } & \multicolumn{3}{|c|}{ Males } & \multicolumn{3}{|c|}{ Females } & \multicolumn{6}{|c|}{ Wilcoxon matched-pairs test } \\
\hline & $25 \%$ & Median & $75 \%$ & $25 \%$ & Median & $75 \%$ & $T$ & df & $P$ & $-95 \%$ & $\begin{array}{l}\text { M diff. } \\
(\hat{\partial}-\hat{q})\end{array}$ & $+95 \%$ \\
\hline \multicolumn{13}{|l|}{ Initial $(n=12$ pairs $)$} \\
\hline Building visits $\left(\mathrm{hr}^{-1}\right)$ & 2.6 & 6.3 & 9.8 & 3.4 & 7.2 & 11.3 & 22 & 11 & 0.18 & -8.5 & -1.5 & 1.5 \\
\hline Mud-carrying visits $\left(\mathrm{hr}^{-1}\right)$ & 0.8 & 3.5 & 5.7 & 0.6 & 5.6 & 8.6 & 10 & 11 & 0.02 & -2.75 & -1.5 & -0.3 \\
\hline \multicolumn{13}{|l|}{ Advanced ( $n=19$ pairs) } \\
\hline Building visits $\left(\mathrm{hr}^{-1}\right)$ & 1 & 1.5 & 6.5 & 1 & 3 & 7.5 & 25 & 18 & 0.48 & -1.5 & -0.5 & 0.5 \\
\hline Mud-carrying visits $\left(\mathrm{hr}^{-1}\right)$ & 0.5 & 2.5 & 8 & 3.5 & 5.5 & 7.5 & 23 & 18 & 0.21 & -3.5 & -2.5 & 0.5 \\
\hline
\end{tabular}


TABLE 2. Frequency of uncoordinated behaviors of males and females during different stages of the nesting period (see Methods). The contribution of each sex is compared by a Wilcoxon matched-pairs test and the $95 \%$ confidence interval for the difference between median values for males and females ( $\mathrm{M}$ diff. $\left.\partial^{\lambda}-q\right)$.

\begin{tabular}{|c|c|c|c|c|c|c|c|c|c|c|c|c|}
\hline \multirow[b]{2}{*}{ Stage and variable } & \multicolumn{3}{|c|}{ Males } & \multicolumn{3}{|c|}{ Females } & \multicolumn{6}{|c|}{ Wilcoxon matched-pairs test } \\
\hline & $25 \%$ & Median & $75 \%$ & $25 \%$ & Median & $75 \%$ & $T$ & $\mathrm{df}$ & $P$ & $-95 \%$ & $\begin{array}{l}\text { M diff. } \\
(\hat{\delta}-\emptyset)\end{array}$ & $+95 \%$ \\
\hline \multicolumn{13}{|l|}{ Nest building } \\
\hline \multicolumn{13}{|l|}{ Initial ( $n=12$ pairs $)$} \\
\hline Building visits $\left(\mathrm{hr}^{-1}\right)$ & 2.6 & 6.3 & 9.8 & 3,4 & 7.2 & 11.3 & 22 & 11 & 0.18 & -8.5 & -1.5 & 1.5 \\
\hline Mud-carrying visits $\left(\mathrm{hr}^{-1}\right)$ & 0.8 & 3.5 & 5.7 & 0,6 & 5.6 & 8.6 & 6.5 & 11 & 0.02 & -2.75 & -1.75 & -0.75 \\
\hline \multicolumn{13}{|l|}{ Advanced ( $n=19$ pairs $)$} \\
\hline Building visits $\left(\mathrm{hr}^{-1}\right)$ & 0.5 & 0 & 1.25 & 1.5 & 0.5 & 3.5 & 29.5 & 18 & 0.15 & -1.25 & -0.5 & 0.15 \\
\hline Mud carrying visits $\left(\mathrm{hr}^{-1}\right)$ & 0 & 0 & 0.5 & 0.5 & 0 & 1 & 19.5 & 18 & 0.23 & -1 & -0.5 & 1 \\
\hline \multicolumn{13}{|c|}{ Feeding and brooding } \\
\hline \multicolumn{13}{|c|}{ Initial feeding period ( $n=23$ pairs) } \\
\hline Feeding $\left(\mathrm{hr}^{-1}\right)$ & 1 & 2 & 3 & 5 & 2 & 8 & 48.5 & 22 & 0.006 & -1.5 & -2.5 & \\
\hline Brooding $\left(\mathrm{hr}^{-1}\right)$ & 0 & 0 & 1 & 2 & 1 & 3 & 25 & 22 & 0.009 & -2.75 & -1.75 & -0.75 \\
\hline \multicolumn{13}{|c|}{ Middle feeding period ( $n=23$ pairs) } \\
\hline Feeding $\left(\mathrm{hr}^{-1}\right)$ & 0.5 & 0 & 1.25 & 1.5 & 0.5 & 3.5 & 29.5 & 22 & 0.15 & -1.25 & -0.5 & 0.15 \\
\hline \multicolumn{13}{|c|}{ Final feeding period ( $n=12$ pairs) } \\
\hline Feeding $\left(\mathrm{hr}^{-1}\right)$ & 2.75 & 5.25 & 11.5 & 2.75 & 4.75 & 9.5 & 37 & 11 & 0.87 & -2 & -0.25 & 7.5 \\
\hline
\end{tabular}

TABLE 3. Median, lower, and upper quartiles of the length (min:sec) and frequency of incubation shifts by males and females during the initial, middle, and advanced stages of incubation (see Methods). The effort of each sex is compared by a Wilcoxon matched-pairs test and the $95 \%$ confidence interval for the difference between median values for males and females ( $\mathrm{M}$ diff. $\hat{\sigma}-q) ; \mathrm{df}=22$ for all tests.

\begin{tabular}{|c|c|c|c|c|c|c|c|c|c|c|c|}
\hline \multirow[b]{2}{*}{ Stage and variable } & \multicolumn{3}{|c|}{ Males } & \multicolumn{3}{|c|}{ Females } & \multicolumn{5}{|c|}{ Wilcoxon matched-pairs test } \\
\hline & $25 \%$ & Median & $75 \%$ & $25 \%$ & Median & $75 \%$ & $T$ & $P$ & $-95 \%$ & $\begin{array}{l}\text { M diff. } \\
(\widehat{\delta}-q)\end{array}$ & $+95 \%$ \\
\hline \multicolumn{12}{|l|}{ Initial $(n=23$ pairs $)$} \\
\hline Mean length of visits (min:sec) & $04: 50$ & $07: 40$ & $13: 40$ & $06: 40$ & $12: 30$ & $19: 22$ & 82 & 0.09 & 00:00 & $03: 50$ & $04: 30$ \\
\hline Visits $\left(\mathrm{hr}^{-1}\right)$ & 0.7 & 1.4 & 2.0 & 1.5 & 1.7 & 2.48 & 48 & 0.03 & -1.0 & -0.7 & -0.2 \\
\hline \multicolumn{12}{|c|}{ Middle ( $n=19$ pairs $)$} \\
\hline Mean length of visits (min:sec) & 00:00 & $11: 20$ & $49: 30$ & $05: 40$ & $14: 50$ & $40: 30$ & 74 & 0.15 & 00:00 & $02: 20$ & $05: 20$ \\
\hline Visits $\left(\mathrm{hr}^{-1}\right)$ & 0 & 1.9 & 2.8 & 0.5 & 1.9 & 2.8 & 58 & 0.60 & -0.5 & -0.1 & 0.3 \\
\hline \multicolumn{12}{|c|}{ Advanced ( $n=21$ pairs $)$} \\
\hline Mean length of visits (min:sec) & 09:00 & $12: 50$ & $17: 00$ & $14: 00$ & $15: 30$ & $17: 40$ & 47 & 0.16 & 00:00 & $02: 50$ & $06: 10$ \\
\hline Visits $\left(\mathrm{hr}^{-1}\right)$ & 1.0 & 1.6 & 2.1 & 1.4 & 1.6 & 2.2 & 23 & 0.37 & -0.5 & -0.2 & 0.3 \\
\hline
\end{tabular}

building such a massive nest is a compelling example of the amount of parental effort birds may be willing to commit even before the eggs are laid. Because it is unlikely that the building of this nest could be attempted by a single or insufficiently aided partner, we suggest the coordination during nest building may serve as an indication of mates' general compatibility and the contribution of each to parental care during the rest of the reproductive effort. The idea that early effort indicates later compatibility in this species, however, needs to be studied with repeated measures of behavior through the nesting cycle.

Males, in turn, were more involved than females in early incubation but contributed the same as females during middle and late incubation. The proportion of coordinated behavior during early and middle incubation was high (0.8) and rose to 0.9 by late incubation; the uncoordinated visits were so few as to preclude any statistical comparison. The male's participation in incubation is smaller than that of females in some species (Reid et al. 2002b, Bartlett et al. 2005) and equal or higher in others (Van Roo et al. 2003, Auer et al. 2006, Hogstad 2009), but those investigations did not evaluate the degree of coordination of the behavior between the sexes. The elevated coordination of incubation behavior might affect hatching and nesting success, eventually determining the duration of the pair bond in successive years. Delays in incubation relays are 
TABLE 4. Median, lower, and upper quartiles of variables measured in the nestling period (frequency of feeding, brooding, and removal of fecal sacs and duration of brooding by males and females (see Methods). The effort of each sex is compared by a Wilcoxon matched-pairs tests and $95 \%$ confidence interval for the difference between median values for males and females (M diff. $\hat{\delta}-\mathcal{q}$ ).

\begin{tabular}{|c|c|c|c|c|c|c|c|c|c|c|c|c|}
\hline \multirow[b]{2}{*}{ Stage and variable } & \multicolumn{3}{|c|}{ Males } & \multicolumn{3}{|c|}{ Females } & \multicolumn{6}{|c|}{ Wilcoxon matched-pairs test } \\
\hline & $25 \%$ & Median & $75 \%$ & $25 \%$ & Median & $75 \%$ & $T$ & df & $P$ & $-95 \%$ & $\begin{array}{l}\text { M diff. } \\
(\hat{0}-q)\end{array}$ & $+95 \%$ \\
\hline \multicolumn{13}{|l|}{ Initial ( $n=14$ nests $)$} \\
\hline Feeding visits per nestling $\left(\mathrm{hr}^{-1}\right)$ & 1.1 & 1.6 & 2.4 & 1.5 & 1.9 & 2.5 & 68 & 13 & 0.03 & -0.6 & -0.3 & -0.1 \\
\hline Brooding visits per nestling $\left(\mathrm{hr}^{-1}\right)$ & 0.5 & 0.7 & 0.9 & 0.7 & 0.9 & 1.2 & 39 & 13 & 0.04 & -0.4 & -0.02 & -0.05 \\
\hline Average brooding (min:sec) & $07: 10$ & 09:50 & $14: 10$ & $09: 40$ & $14: 00$ & $18: 00$ & 68 & 13 & 0.03 & $00: 00$ & $05: 10$ & $12: 10$ \\
\hline \multicolumn{13}{|l|}{ Middle $(n=15$ nests $)$} \\
\hline Feeding visits per nestling $\left(\mathrm{hr}^{-1}\right)$ & 3.2 & 4.1 & 4.8 & 2.1 & 3.6 & 5.6 & 77 & 13 & 0.30 & -0.3 & 0.4 & 0.9 \\
\hline Sac-removal visits per nestling $\left(\mathrm{hr}^{-1}\right)$ & 0.2 & 0.4 & 0.7 & 0.2 & 0.3 & 0.5 & 81 & 13 & 0.57 & -0.1 & 0.10 & 0.12 \\
\hline \multicolumn{13}{|l|}{ Advanced ( $n=21$ nests $)$} \\
\hline Feeding visits per nestling $\left(\mathrm{hr}^{-1}\right)$ & 4.7 & 5.7 & 8.9 & 4.2 & 6.3 & 6.9 & 85 & 13 & 0.45 & -0.5 & 0.5 & 1.6 \\
\hline Sac-removal visits per nestling $\left(\mathrm{hr}^{-1}\right)$ & 0.6 & 0.7 & 1.1 & 0.5 & 0.8 & 1.0 & 95 & 13 & 0.48 & -0.1 & 0.0 & 0.4 \\
\hline
\end{tabular}

known to affect the duration of marine birds' pair bond within a breeding season, usually because of the constraints of energetic demands (Davis 1988, Dearborn 2001). A similar scenario would not be expected in a species such as the Rufous Hornero that is territorial year round, but it could be of importance in divorce rates, as in the territorial Lesser Spotted Woodpecker (Dendrocopos minor; Wiktander et al. 2000). This aspect of the Rufous Hornero's behavior awaits further study.

Male Rufous Horneros also participated actively in brooding, though females made more and longer visits to brood. Although pairs' coordination in brooding nestlings was relatively high, females made more uncoordinated visits than did males. This rather small difference between the sexes in brooding behavior is surprising as males of other species are not often involved in this task. Finally, we found no differences in the rate of feeding the nestlings in two of the three intervals sampled and no differences in rates of removal of fecal sacs. The majority of feeding visits were coordinated during the nestling period, and uncoordinated visits were similar in frequency for males and females.

Significant biparental care is generally associated with monogamy and is the most common pattern of parental care among birds (Lack 1968). However, since the earliest molecular assessments of paternity among birds (Burke and Bruford 1987), deviations from monogamy have been found. In a comparative study, Owens and Hartley (1998) found that social monogamy is related to the reduction or loss of sexual size dimorphism, and in species with little or no sexual size dimorphism the rates of extra-pair mating and extra-pair paternity tend to be low. As suggested by Remsen (2003), the Rufous Hornero is a good candidate for social and genetic monogamy because: (1) it shows no sexual size or color dimorphism (at least to the human eye), (2) pairs remain together through the breeding season and sometimes for multiple years (Fraga 1980), (3) the construction of an ovenlike nest that weighs up to 80 times the weight of each bird is a monumental task, likely impossible for a single individual, (4) pairs are territorial year round, forage together, and both sexes repel conspecifics from the territory (Fraga 1980), (5) they sing in duets, a characteristic associated with high levels of territorial and pair defense from conspecifics (Hahn et al. 2004), and (6) both sexes make a high and equitable investment in all stages of the reproductive effort. The equitability and high coordination of parental duties we found suggest males have high confidence in their paternity and invest in the nestlings accordingly, making this species a good candidate for genetic monogamy. Future studies of paternity will allow this hypothesis to be tested.

\section{ACKNOWLEDGMENTS}

We thank M. E. Lahaye and F. Bulit for their field assistance. We are indebted to G. Somoza, L. Miranda, and C. Frasch, who provided logistic support at the IIB-INTECH-CONICET. We are grateful to Diane Landoll for her dedication and perceptive comments in reviewing the manuscript and to one anonymous reviewer. This study was made possible by University of Buenos Aires grants UBACyT to VM and JCR. VM and JCR are research fellows of CONICET, and GCL is an adjunct professional histotechnologist at CONICET.

\section{LITERATURE CITED}

Aldatz, M. F. 2006. Biología reproductiva y cuidado parental en el Hornero Común, Furnarius rufus. Tesis de Licenciatura, Universidad de Buenos Aires, Buenos Aires Argentina.

Auer, S. K., R. D. Bassar, AND T. E. MARTIN. 2007. Biparental incubation in the Chestnut-vented Tit-babbler (Parisoma subcaeruleum): mates devote equal time, but males keep eggs warmer. Journal of Avian Biology 38:278-283.

Bartlett, T. L., D. W. Mock, And P. L. Schwagmeyer. 2005. Division of labor: incubation and biparental care in House Sparrows (Passer domesticus). Auk 122:835-842. 
Burke, T., AND M. W. BRUFORD. 1987. DNA fingerprinting in birds. Nature 327:149-152.

Clutton-Brock, T. H. 1991. The evolution of parental care. Princeton University Press, Princeton, NJ.

Colegrave, N., AND G. D. RuXton. 2003. Confidence intervals are a more useful complement to nonsignificant tests than are power calculations. Behavioral Ecology 14:446-450.

DAnIEL, W. W. 1978. Applied nonparametric statistics. Houghton Mifflin, Boston.

DAVIS, L. S. 1988. Coordination in incubation routines and mate choice in Adélie Penguins (Pygoscelis adeliae). Auk 105:428-432.

DEArborn, D. C. 2001. Body condition and retaliation in the parental effort decisions of incubating Great Frigatebirds (Fregata minor). Behavioral Ecology 12:200-206.

Dingemanse, N. J., C. Both, P. J. Drent, And J. M. Tinbergen. 2004. Fitness consequences of avian personalities in a fluctuating environment. Proceedings of the Royal Society of London B 271:847-852.

EMLEN, S. T., AND L. W. ORING. 1977. Ecology, sexual selection, and the evolution of mating systems. Science 197:215-223.

Ens, B. J., U. N. Safriel, And M. P. Harris. 1993. Divorce in the long-lived and monogamous oystercatcher, Haematopus ostralegus: incompatibility or choosing the better option? Animal Behaviour 45:1199-1217.

FRAGA, R. 1980. The breeding of Rufous Horneros (Furnarius rufus). Condor 82:58-68.

FridolfSSON, A. K., AND H. Ellegren. 1999. A simple and universal method for molecular sexing of non-ratite birds. Journal of Avian Biology 30:116-121.

Griffith, S. C., I. P. F. Owens, And K. A. Thuman. 2002. Extra-pair paternity in birds: a review of interspecific variation and adaptative function. Molecular Ecology 11:2195-2212.

Hahn, I., U. RöMERT, AND R. Schlatter. 2004. Nest sites and breeding ecology of the Másafuera Rayadito (Aphrastura masafuerae) on Alejandro Selkirk Island, Chile. Journal of Ornithology 145:93-97.

Hogstad, O. 2009. Sexual differences of labour during breeding activities and territory use in the Lesser Spotted Woodpecker (Dendrocopos minor). Ornis Norvegica 32:42-48.

Ketterson, E. D., AND V. Nolan. 1994. Male parental behavior in birds. Annual Review of Ecology and Systematics 25:601-628.

LACK, D. 1968. Ecological adaptations for breeding in birds. Methuen, London.

MASON, P. 1985. The nesting biology of some passerines of Buenos Aires, Argentina. Ornithological Monographs 36:954-972.

Moreno, J., S. Merino, E. Lobato, M. A. Rodríguez-Gironés, And R. A. VÁsQuez. 2007. Sexual dimorphism and parental roles in the Thorn-tailed Rayadito (Furnariidae). Condor 109:312-320.

NARosky, T., AND D. Yzurieta. 1987. Guía para la identificación de las aves de Argentina y Uruguay. Vazquez Mazzini, Buenos Aires.

Nores, A. I., AND M. Nores. 1994. Nest building and nesting behavior of the Brown Cachalote. Wilson Bulletin 106:106-120.
Owens, I. P. F., AND I. R. HaRtLey. 1998 Sexual dimorphism in birds: why are there so many different forms of dimorphism? Proceedings of the Royal Society of London B 265:397-407.

Pearson, J. T. 1994.Oxygen consumption rates of adults and chicks during brooding in King Quail Coturnix chinensis. Journal of Comparative Physiology B 164:415-424.

Quintana, F., G. C. López, and G. Somoza. 2008. A quick and cheap method for DNA-based sexing of birds. Waterbirds 31:485-488.

Reid, J. M., P. Monaghan, And R. G. Nager. 2002a. Incubation and the costs of reproduction, p. 314-325. In D. C. Deeming [ED.] Avian incubation: behavior, environment and evolution. Oxford University Press, New York.

Reid, J. M., P. Monaghan, And G. D. RuXton. 2002b. Males matter: the occurrence and consequences of male incubation in starlings (Sturnus vulgaris). Behavioral Ecology and Sociobiology 51:255-261.

Remsen, J. V. 2003. Family Furnariidae (ovenbirds), p. 162-357. In J. del Hoyo, A. Elliott, and D. Christie [EDS.] Handbook of the birds of the world, vol 8. Lynx Edicions, Barcelona.

Roper, J. J. 2005. Sexually distinct songs in the duet of the sexually monomorphic Rufous Hornero. Journal of Field Ornithology 76:234-236.

Silver, R., H. ANDrews, AND G. F. BALl. 1985. Parental care in an ecological perspective: a quantitative analysis of avian subfamilies. American Zoologist 25:823-840.

Soriano, O. 1991. Río de La Plata grassland, p. 367-407. In R. T. Coupland [ED.], Natural grasslands. Introduction and Western Hemisphere. Elsevier, Amsterdam.

Spoon, T. R., J. R. Millam, and D. H. Owings. 2006. The importance of mate behavioural compatibility in parenting and reproductive success by Cockatiels (Nymphicus hollandicus). Animal Behaviour 71:315-326.

Trivers, R. L. 1972. Parental investment and sexual selection, $p$. 136-179. In B. Campbell [ED.], Sexual selection and the descent of man. Aldine Press, Chicago.

VAn Roo, B. L, E. D. Ketterson, And P. J. Sharp. 2003. Testosterone and prolactin in two songbirds that differ in paternal care: the Blue-headed Vireo and the Red-eyed Vireo. Hormones and Behavior 44:435-441.

Whittingham, L. A., And P. O. Dunn. 2001. Male parental care and paternity in birds, p. 257-298. In V. Nolan Jr. and C. F. Thompson [EDS.], Current ornithology. Plenum, New York.

Wiktander, U., O. Olson, AND S. G. Nilsson. 2000. Parental care and social mating system in the Lesser Spotted Woodpecker (Dendrocopos minor). Journal of Avian Biology 31:447-456.

WiLliams, J. B. 1996. Energetics of avian incubation, p. 375-416. In C. Carey [ED.], Avian energetics and nutritional ecology. Chapman and Hall, New York.

ZEH, J. A., AND D. W. ZEH. 2001. Reproductive mode and the genetic benefits of polyandry. Animal Behaviour 61:1051-1063. 